\section{SOI: $1.1 /$ TAS $\quad$ DOI: $10.15863 /$ TAS International Scientific Journal Theoretical \& Applied Science}

p-ISSN: 2308-4944 (print) e-ISSN: 2409-0085 (online)

Year: $2018 \quad$ Issue: $01 \quad$ Volume: 57

Published: 13.01.2018 http://T-Science.org

SECTION 2. Applied mathematics. Mathematical modeling.

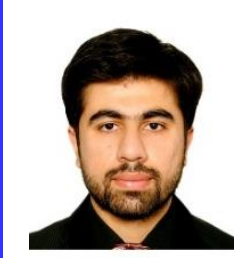
Department of Energy Systems Engineering, US Pakistan Center for Advanced Studies in Energy (USPCASE),

National University of Sciences and Technology (NUST), Islamabad, Pakistan mali27@asu.edu

Safi Ahmad

Department of Mechanical Engineering, Ghulam Ishaq Khan Institute of Engineering Sciences and Technology, Topi, Pakistan gme1539@giki.edu.pk

\title{
NUMERICAL ANALYSIS OF ENTROPY GENERATION AND PRESSURE DROP PERFORMANCE OF PHASE CHANGE MATERIAL SLURRIES IN MICROCHANNELS OF HIGH HEAT GENERATING ELECTRONIC DEVICES
}

\begin{abstract}
This numerical study investigates the effect of using phase change material slurries (PCMs) on the hydraulic performance of microchannel. The phase change material slurries composed of Dodecanoic acid (PCM nanoparticles) in water (carrier fluid) which is introduced into a rectangular microchannel of $100 \mu \mathrm{m}$ height and $10 \mathrm{~mm}$ length, where bottom wall face a constant heat flux. Energy, momentum and mass equations are solved simultaneously using a carrier fluid with effective temperature dependent physical properties. Under specific conditions including mass flow rate of $1 \times 10-4 \mathrm{~kg} / \mathrm{s}$, heat flux of $0.7 \mathrm{MW} / \mathrm{m} 2$ and PCM nano-particles volume concentration (0-25\%), results showed a remarkable increase in the effectiveness ratio, pressure drop, pumping power and entropy generation. Effectiveness index is used to measure the effectiveness of PCM slurries.

Key words: Microchannel, Phase Change Material, PCM Slurry, Pressure Drop, Entropy Generation

Language: English

Citation: Ali M, Ahmad S (2018) NUMERICAL ANALYSIS OF ENTROPY GENERATION AND PRESSURE DROP PERFORMANCE OF PHASE CHANGE MATERIAL SLURRIES IN MICROCHANNELS OF HIGH HEAT GENERATING ELECTRONIC DEVICES. ISJ Theoretical \& Applied Science, 01 (57): 1-8.

Soi: http://s-o-i.org/1.1/TAS-01-57-1 Doi: crossef https://dx.doi.org/10.15863/TAS.2018.01.57.1
\end{abstract}

\section{INTRODUCTION}

Many methods for cooling of small scale heat generating devices have been presented in previous few years [1]. One latest method gaining importance is using Phase Change Material particles with fluid in microchannels, this improve the heat storage capacity and helps in effective heat removal [1-11]. The drawback of this method is that by increasing the PCM particles volume concentration in the slurry, viscosity of slurry also increases which in turn increase the pumping power demands and entropy generation [2].

The previous work performed on three dimensional numerical study of temperature dependent physical properties of PCM carrying fluid having melting range of $300-305 \mathrm{~K}$ and inlet temperature $300 \mathrm{~K}$ in rectangular microchannels and increase in heat transfer coefficient and temperature reduction with increase of PCM particles volume concentration recorded [3].

The work presented in this paper is performed for 2D study of microchannel with Dodecanoic acid nanoparticles, having melting range of 316.7-317.7K and inlet temperature $315 \mathrm{~K}$ in carrier fluid (water) on different operating conditions [1]. The present work takes into account the enhancement in pressure drop, pumping power and entropy generation with increasing Dodecanoic acid particles in carrier fluid (water). Table 1 summarize the properties of the PCM Nanoparticles [4] 


\begin{tabular}{l|lr|ll|ll} 
& ISRA (India) & $=\mathbf{1 . 3 4 4}$ & SIS (USA) & $=\mathbf{0 . 9 1 2}$ & ICV (Poland) & $=\mathbf{6 . 6 3 0}$ \\
Impact Factor: & ISI (Dubai, UAE) $=\mathbf{0 . 8 2 9}$ & PVHU (Russia) $=\mathbf{0 . 2 0 7}$ & PIF (India) & $=\mathbf{1 . 9 4 0}$ \\
& GIF (Australia) & $\mathbf{0 . 5 6 4}$ & ESJI (KZ) & $\mathbf{4 . 1 0 2}$ & IBI (India) & $\mathbf{4 . 2 6 0}$
\end{tabular}

Table 1

Physical Properties of Dodecanoic acid [4]

\begin{tabular}{|c|c|c|c|c|}
\hline $\begin{array}{c}\text { Dodecanoic acid } \\
\text { Particles }\end{array}$ & $\begin{array}{c}\text { Density } \\
(\mathbf{k g} / \mathbf{m 3})\end{array}$ & $\begin{array}{c}\text { Specific heat } \\
(\mathbf{k J} / \mathbf{k g ~ K})\end{array}$ & $\begin{array}{c}\text { Latent heat } \\
(\mathbf{k J} / \mathbf{k g})\end{array}$ & $\begin{array}{c}\text { Thermal conductivity } \\
(\mathbf{W} / \mathbf{m ~ K})\end{array}$ \\
\hline Solid & 1007 & 1.76 & 211 & 0.147 \\
\hline Liquid & 862 & 2.27 & -- & 0.147 \\
\hline
\end{tabular}

\section{Materials and methods}

Fig.1 shows the schematic diagram of microchannel used in this study. In this study a microchannel of fixed height $(\mathrm{H}) 100 \mu \mathrm{m}$ and length (L) $10 \mathrm{~mm}$ is defined in ANSYS-FLUENT 15.0. For three-dimensional study the width $(\mathrm{W})$ of the channel is considered to be $1 \mathrm{~mm}$. PCM slurry introduced to the inlet of microchannel at mass flow rate of $1 \times 10^{-4}$ $\mathrm{kg} / \mathrm{s}$ and inlet temperature of $315 \mathrm{~K}$ below the melting temperature $(317.2 \mathrm{~K})$ of PCM nano-particles. At outlet of microchannel the pressure of $1 \mathrm{~atm}$ is assumed. A constant heat flux of $0.7 \mathrm{MW} / \mathrm{m}^{2}$ is generated at the bottom wall of microchannel which heats the PCM slurry flowing in microchannel.

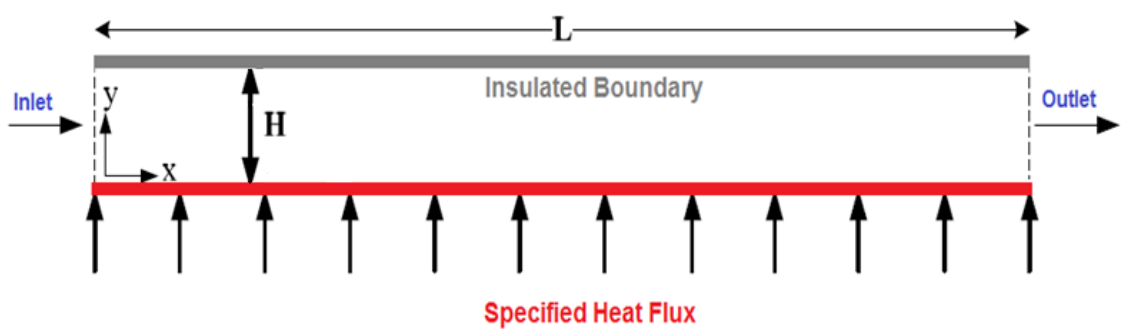

Figure 1- Schematic of microchannel used in this study. [1]

\section{Assumption:}

$\square \quad$ PCM slurry flowing inside the microchannel is steady, viscos, incompressible and laminar [1].

$\square$ Physical properties (density, viscosity, specific heat capacity, thermal conductivity) of carrier fluid (water) are temperature dependent [3].

$\square \quad$ PCM slurry physical properties are function of particles volume concentration and temperature dependent [3].

$\square \quad$ Shell encapsulating nanoparticles has no effect of PCM slurry performance [5].

$\square \quad$ The carrier fluid and PCM particles are flowing with same temperature and velocity [5].

$\square \quad$ Homogenous distribution of Nanoparticles are assumed [5].

$\square \quad$ When PCM particles reached the melting temperature range, they melts instantly [5].

\section{Governing Equations}

Energy, Momentum and Mass governing equations are solved simultaneously using temperature dependent physical properties of PCM slurries given below:
1) Conversation of Energy Equation [1]

$$
\nabla \cdot\left(\rho_{p c m s} \vec{v} c_{p p c m s} T\right)=\nabla \cdot\left(k_{p c m s} \nabla T\right)
$$

2) Conversation of Momentum [1]

$$
\nabla \cdot\left(\rho_{p c m s} \vec{v} \vec{v}\right)=-\nabla \rho+\mu_{p c m s} \nabla^{2} v
$$

3) Conversation of Mass [1]

$$
\nabla \cdot \vec{v}=0
$$

Temperature Dependent Physical Properties of PCM Slurry

1) Density: Density of PCM slurry (pcms) is calculated as [3]

$$
\rho_{p c m s}=c \rho_{p}+(1-c) \rho_{c f}
$$

2) Specific Heat Capacity: Melting temperature of $317.2 \mathrm{~K}$ and melting range of 316.7-317.7K for Dodecanoic acid nanoparticles is assumed in this study [1]. Specific heat capacity of PCM slurry (pcms) is calculated as [3-4] 


\begin{tabular}{|c|c|c|c|c|c|c|}
\hline Impact Factor: & $\begin{array}{l}\text { ISRA (India) } \\
\text { ISI (Dubai, UAE } \\
\text { GIF (Australia) } \\
\text { JIF }\end{array}$ & $\begin{array}{l}=1.344 \\
=0.829 \\
=0.564 \\
=1.500\end{array}$ & $\begin{array}{l}\text { SIS (USA) } \\
\text { PИНЦ (Russia } \\
\text { ESJI (KZ) } \\
\text { SJIF (Morocco }\end{array}$ & $\begin{array}{l}=0.912 \\
=0.207 \\
=\mathbf{4 . 1 0 2} \\
=\mathbf{2 . 0 3 1}\end{array}$ & $\begin{array}{l}\text { ICV (Poland) } \\
\text { PIF (India) } \\
\text { IBI (India) }\end{array}$ & $\begin{array}{l}=6.630 \\
=1.940 \\
=4.260\end{array}$ \\
\hline
\end{tabular}

For $T_{p}<T_{\text {Solidus }}$ :

$c_{p p c m s}=\frac{c\left(\rho c_{p, S}\right)_{p}+(1-c)\left(\rho c_{p}\right)_{c f}}{\rho_{p c m s}}$

For $T_{\text {Solidus }}<T_{p}<T_{\text {liquidus }}$ :

$c_{\text {ppcms }}=\frac{c\left(\rho\left(\frac{c_{p s} c_{p L}}{2}+\frac{L}{T_{\text {liquidus }}-T_{\text {Solidus }}}\right)\right)_{p}+(1-c)\left(\rho c_{p}\right)_{c f}}{\rho_{\text {pcms }}}$

For $T_{p}>T_{\text {liquidus }}:$

$c_{p p c m s}=\frac{c\left(\rho c_{p, L}\right)_{p}+(1-c)\left(\rho c_{p}\right)_{c f}}{\rho_{p c m s}}$

3) Viscosity: The viscosity of PCM slurry increases with the addition of PCM particles, which is calculated as [12]

$$
\mu_{p c m s}=\left(1-c-1.16 c^{2}\right)^{-2.5} \mu_{c \text { s }}
$$

4) Thermal Conductivity: Thermal conductivity of PCM slurry (pcms) is calculated as [13]

$$
k_{p c m s}=k_{c f} \frac{2+k_{p} / k_{c f}+2 c\left(k_{p} / k_{c f}-1\right)}{2+k_{p} / k_{c f}-c\left(k_{p} / k_{c f}-1\right)}
$$

\section{Numerical Method}

A 2D geometry and Mesh is created in ANSYSFLUENT 15.0 in order to discretize the governing equations, control volume approach of Simple Algorithm is utilize the second order upwind scheme. For energy, momentum and mass equations residuals of $10^{-6}, 10^{-3}$ and $10^{-3}$ applied respectively.

\section{Grid Independence Test}

Different grid resolutions were created in ANSYS-FLUENT15.0 as $10 \times 1000, \quad 15 \times 4000$, $20 \times 8000$ and $22 \times 10000$. The maximum difference between the Nusselt number results of grid resolution $20 \times 8000$ and $22 \times 10000$ was 0.002 as shown in Fig. 2. Therefore Grid 20x8000 used for simulations.

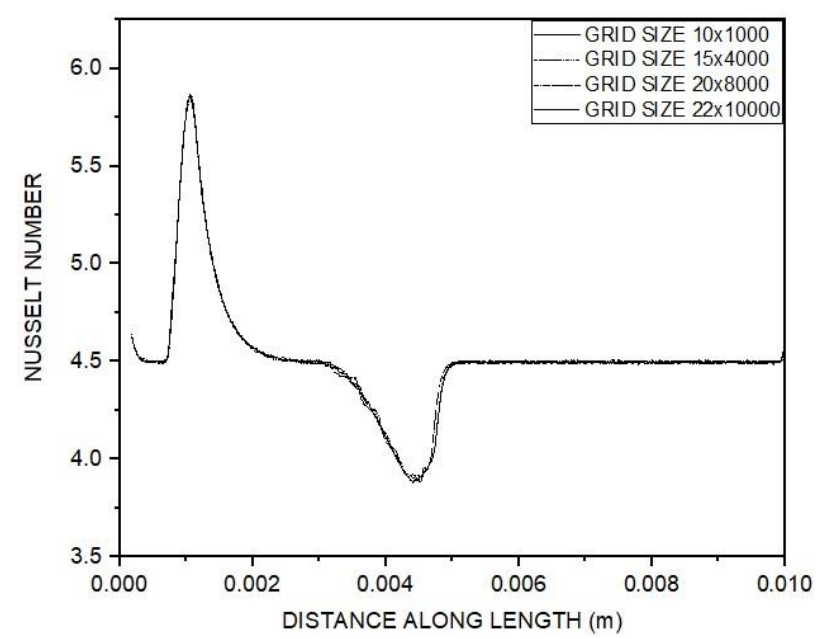

Figure 2 - Grid independence test

\section{Significance of Temperature Dependent Properties}

Temperature dependent physical properties for carrier fluid (water) are used in this study. Importance of using temperature dependent physical properties rather than constant temperature physical properties is shown in Table 2 [3]. The percentage difference in pressure drop along the microchannel is $114 \%$. The reason behind this huge difference in pressure drop is viscosity of carrier fluid (water), which is highly sensitive to temperature. So, on the basis of results in Table 2, the simulations are performed with temperature dependent physical properties.

\section{Significance of Temperature dependent physical properties [3]}

Table 2

\begin{tabular}{|l|c|c|c|c|c|}
\hline \multicolumn{2}{|c|}{ Constant Properties } & Temperature dependent properties & \multicolumn{2}{c|}{ Percentage Difference } \\
\hline $\mathbf{T}_{\text {outlet }}(\mathbf{K})$ & $\Delta \mathbf{P}(\mathbf{P a})$ & $\mathbf{T}_{\text {outlet }}(\mathbf{K})$ & $\Delta \mathbf{P}(\mathbf{P a})$ & $\mathbf{T}_{\text {outlet }}(\boldsymbol{\%})$ & $\Delta \mathbf{P}(\boldsymbol{\%})$ \\
\hline 331.6471 & 16465.62 & 331.7607 & 7684.943 & 0.03 & 114 \\
\hline \multicolumn{4}{|c|}{ Heat Flux $=0.7 \mathrm{MW} / \mathrm{m}^{2}, \quad$ Mass Flow rate $=1 x 10^{-4} \mathrm{~kg} / \mathrm{s}, \quad$ Inlet Temperture $=315 \mathrm{~K}$} \\
\hline
\end{tabular}




\begin{tabular}{|c|c|c|c|c|c|c|}
\hline Impact Factor: & $\begin{array}{l}\text { ISRA (India) } \\
\text { ISI (Dubai, UAE } \\
\text { GIF (Australia) } \\
\text { JIF }\end{array}$ & $\begin{array}{l}=1.344 \\
=0.829 \\
=0.564 \\
=1.500\end{array}$ & $\begin{array}{l}\text { SIS (USA) } \\
\text { PИНЦ (Russia) } \\
\text { ESJI (KZ) } \\
\text { SJIF (Morocco) }\end{array}$ & $\begin{array}{l}=0.912 \\
=0.207 \\
=4.102 \\
=\mathbf{2 . 0 3 1}\end{array}$ & $\begin{array}{l}\text { ICV (Poland) } \\
\text { PIF (India) } \\
\text { IBI (India) }\end{array}$ & $\begin{array}{l}=6.630 \\
=1.940 \\
=4.260\end{array}$ \\
\hline
\end{tabular}

\section{Model Validation with Experimental Work}

Due to absence of experimental data of flow of PCM slurries in microchannels, experimental data presented in [6], was used to validate the homogeneous model presented in this paper. Numerical model was solved for flow of PCM carrying fluid of $10 \%$ PCM particles volume concentration, in circular pipe of diameter $3.14 \mathrm{~mm}$ and length $0.3 \mathrm{~m}$ for Stefan Number 2, same pipe geometry and PCM slurry as used in [6]. The results of wall temperature along the pipe length obtained from numerical model were compared with the experimental results of [6] as shown in Fig. 3, which shows a good agreement with maximum percentage difference of $0.12 \%$.

Stefan number is a ratio of slurry sensible heat capacity to slurry latent heat capacity and defined as [6]

$$
\text { Ste }=\frac{C_{p p c m s} q^{\prime \prime} D_{h} \rho_{p c m s}}{2 k_{p c m s} c L \rho_{p}}
$$

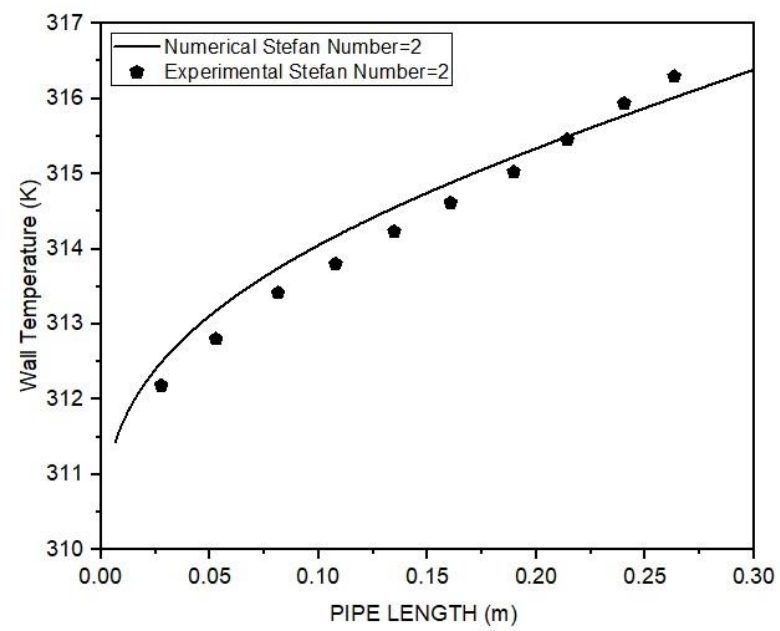

Figure 3 - Comparison of homogenous numerical model with experimental data

\section{Results and Discussions}

\section{Effectiveness ratio}

Effectiveness ratio measures the relative enhancement in heat transfer by adding PCM particles in carrier fluid (water) compared to using water only, defined as [1]

$$
\varepsilon_{f f}=\frac{Q_{p c m s}}{Q_{c f}}
$$

Where, $Q_{p c m s}$ and $Q_{c f}$ are PCM slurry and carrier fluid heat transfers respectively.

$$
\begin{aligned}
& Q_{p c m s}=\text { Length } \times \text { Width } \times q^{\prime \prime} \\
& Q_{c f}=m c_{p c f} \Delta T_{c f}
\end{aligned}
$$

Fig.4 shows the effectiveness ratio as a function of particle volume concentration $(0-25 \%)$ in microchannel at inlet temperature of $315 \mathrm{~K}$, mass flow rate of $1 \times 10^{-4} \mathrm{~kg} / \mathrm{s}$ and heat flux of $0.7 \mathrm{MW} / \mathrm{m}^{2}$. The results show that effectiveness ratio increased by increasing PCM particle volume concentration, but not going up with the addition of PCM particles. As relative percentage increase of $13 \%$ in effectiveness ratio is recorded for 5\% PCM slurry compared to $0 \%$ PCM slurry, where the relative percentage increase of $8 \%$ in effectiveness ratio is recorded for $25 \%$ PCM slurry compared to $20 \%$ PCM slurry. This is because with the addition of PCM particles the viscosity of the fluid increases and slows down the fluid flow [1]. The effectiveness ratio of 1.13, 1.24, $1.34,1.44$ and 1.52 is recorded for $5 \%, 10 \%, 15 \%$, $20 \%$ and $25 \%$ Particle volume concentration. This means that for the same temperature rise, $5 \%, 10 \%$, $15 \%, 20 \%$ and $25 \%$ PCM slurry can store up to $13 \%$, $24 \%, 34 \%, 44 \%$ and $52 \%$ more heat respectively, as compared to $0 \%$ PCM slurry (water). 


\begin{tabular}{l|lr|ll|ll} 
& ISRA (India) & $=\mathbf{1 . 3 4 4}$ & SIS (USA) & $=\mathbf{0 . 9 1 2}$ & ICV (Poland) & $=\mathbf{6 . 6 3 0}$ \\
Impact Factor: & ISI (Dubai, UAE) $=\mathbf{0 . 8 2 9}$ & PVIHL (Russia) $=\mathbf{0 . 2 0 7}$ & PIF (India) & $=\mathbf{1 . 9 4 0}$ \\
& GIIF (Australia) & $\mathbf{0 . 5 6 4}$ & ESJI (KZ) & $=\mathbf{4 . 1 0 2}$ & IBI (India) & $\mathbf{4 . 2 6 0}$
\end{tabular}

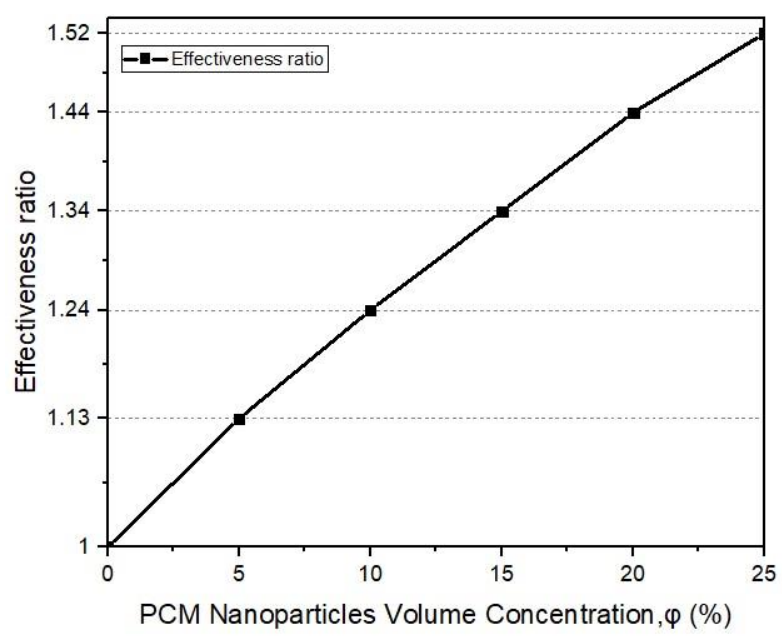

Figure 4 - Effectiveness ratio as a function of particle volume concentration (0-25\%)

\section{Enhancement in Pumping Power}

Pumping power measures the power required to pump the coolant in microchannel, defined as

$$
P P=V A_{\text {flow }} \Delta P
$$

Fig.5 shows the Pumping power as a function of particle volume concentration $(0-25 \%)$ in microchannel at inlet temperature of $315 \mathrm{~K}$, mass flow rate of $1 \times 10^{-4} \mathrm{~kg} / \mathrm{s}$ and heat flux of $0.7 \mathrm{MW} / \mathrm{m}^{2}$. Addition of PCM particles in carrier fluid increase the heat transfer coefficient and reduce the wall temperature in turn improves the performance of microchannel and helps in effective heat removal but drawback of using PCM particles in carrier fluid is that with the addition of PCM particles viscosity of slurry increases and rise the pressure drop [1-3], as shown in Fig 5, which in turn increase the pumping power demands. It is observed that the pumping power is increased by $42 \%, 68 \%, 102 \%, 150 \%$ and $197 \%$ for $5 \%, 10 \%, 15 \%, 20 \%$ and $25 \%$ PCM slurry respectively, as compared to water (0\% PCM slurry).

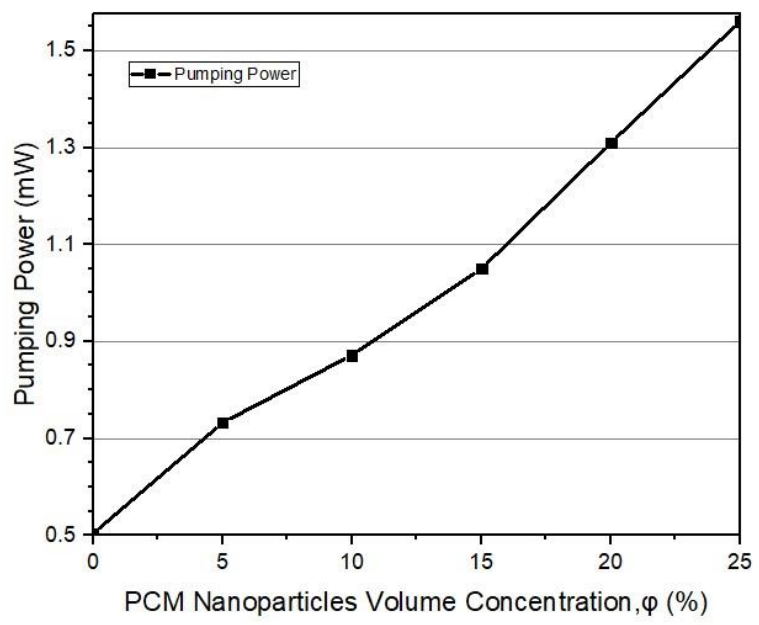

Figure 5 - Pumping power as function of particle volume concentration (0-25\%) 


\begin{tabular}{|c|c|c|c|c|c|c|}
\hline Impact Factor: & $\begin{array}{l}\text { ISRA (India) } \\
\text { ISI (Dubai, UAE } \\
\text { GIF (Australia) } \\
\text { JIF }\end{array}$ & $\begin{array}{l}=1.344 \\
=0.829 \\
=0.564 \\
=1.500\end{array}$ & $\begin{array}{l}\text { SIS (USA) } \\
\text { PИНЦ (Russia) } \\
\text { ESJI (KZ) } \\
\text { SJIF (Morocco }\end{array}$ & $\begin{array}{l}=0.912 \\
=0.207 \\
=4.102 \\
=\mathbf{2 . 0 3 1}\end{array}$ & $\begin{array}{l}\text { ICV (Poland) } \\
\text { PIF (India) } \\
\text { IBI (India) }\end{array}$ & $\begin{array}{l}=6.630 \\
=1.940 \\
=4.260\end{array}$ \\
\hline
\end{tabular}

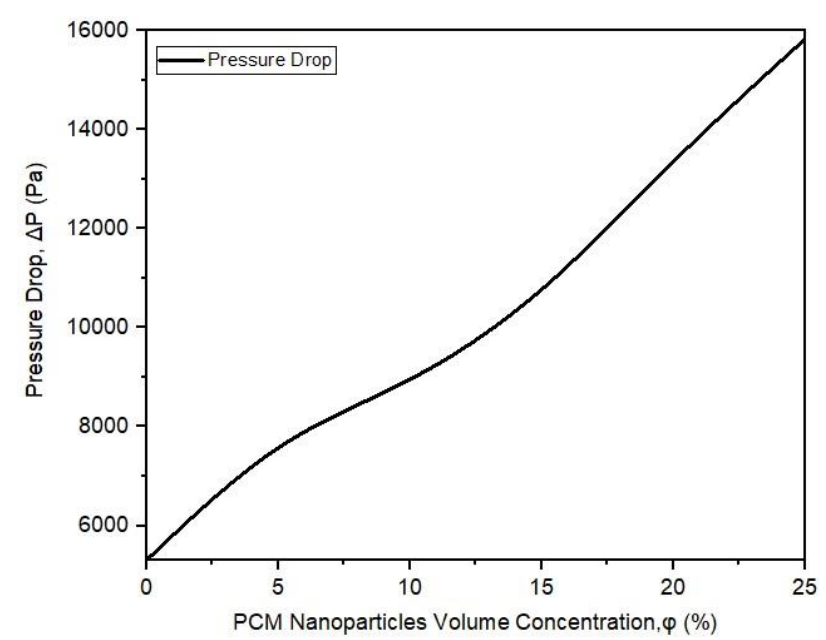

Figure 6 - Pressure drop as function of particle volume concentration $(0-25 \%)$ at inlet temperature $=315 \mathrm{~K}$, mass flow rate $=1 \times 10^{-4} \mathrm{~kg} / \mathrm{s}$, heat flux $=0.7 \mathrm{MW} / \mathrm{m}^{2}$

\section{Volumetric Entropy Generation Rate due to} Heat Transfer

The volumetric entropy generation rate due to heat transfer is defined as [4]

$$
S_{\text {generation_heat_transfer }}^{\prime \prime \prime}=\frac{k_{p c m s}}{T^{2}}\left[\left(\frac{\partial T}{\partial x}\right)^{2}+\left(\frac{\partial T}{\partial y}\right)^{2}\right]
$$

Fig.7 shows the volumetric entropy generation rate due to heat transfer as a function of particle volume concentration $(0-25 \%)$ in microchannel at inlet temperature of $315 \mathrm{~K}$, mass flow rate of $1 \times 10^{-4}$ $\mathrm{kg} / \mathrm{s}$ and heat flux of $0.7 \mathrm{MW} / \mathrm{m}^{2}$.We observed that addition of PCM nano-particles decreases the mean flow temperature of PCM slurry, decreases the thermal conductivity of PCM slurry and increases the temperature gradient along height which leads to increase volumetric entropy generation rate due to heat transfer [4]. It is found that the volumetric entropy generation rate due to heat transfer is increased by $7 \%, 11 \%, 15 \%, 19 \%$ and $21 \%$ for $5 \%$, $10 \%, 15 \%, 20 \%$ and $25 \%$ PCM slurry respectively, as compared to water (0\% PCM slurry).

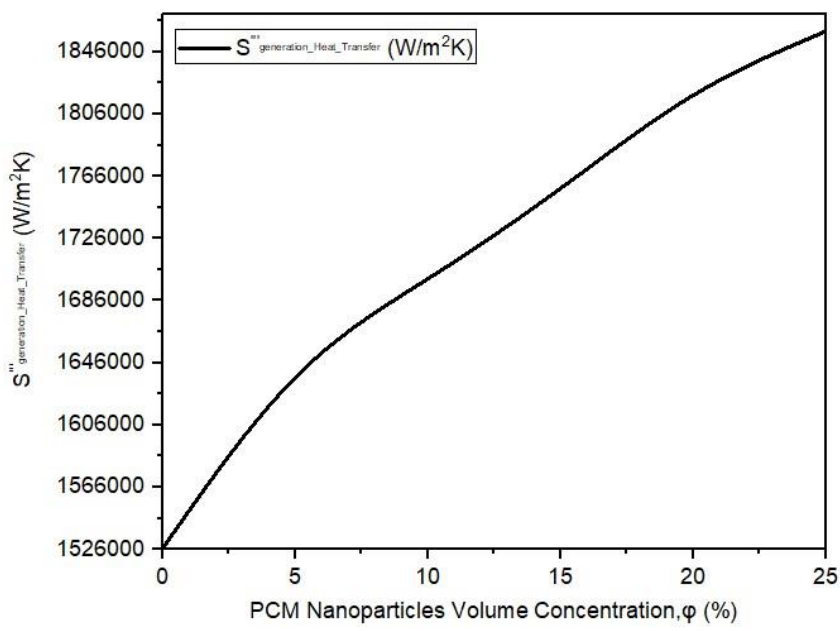

Figure 7 - Volumetric entropy generation rate due to heat transfer as a function of particle volume concentration $(0-25 \%)$

Volumetric Entropy Generation Rate due to Fluid Friction

The volumetric entropy generation rate due to fluid friction is defined as [4]

$$
S_{\text {generation_fluid_friction }}^{\prime \prime \prime}=\frac{\mu_{p c m s}}{T}\left(\frac{\partial u}{\partial y}\right)^{2}
$$

Fig. 8 shows the volumetric entropy generation rate due to fluid friction as a function of particle volume concentration $(0-25 \%)$ in microchannel at 


\begin{tabular}{|c|c|c|c|c|c|c|}
\hline Impact Factor: & $\begin{array}{l}\text { ISRA (India) } \\
\text { ISI (Dubai, UAE } \\
\text { GIF (Australia) } \\
\text { JIF }\end{array}$ & $\begin{array}{l}=1.344 \\
=0.829 \\
=0.564 \\
=1.500\end{array}$ & $\begin{array}{l}\text { SIS (USA) } \\
\text { PИНЦ (Russia } \\
\text { ESJI (KZ) } \\
\text { SJIF (Morocco }\end{array}$ & $\begin{array}{l}=0.912 \\
=0.207 \\
=\mathbf{4 . 1 0 2} \\
=\mathbf{2 . 0 3 1}\end{array}$ & $\begin{array}{l}\text { ICV (Poland) } \\
\text { PIF (India) } \\
\text { IBI (India) }\end{array}$ & $\begin{array}{l}=6.630 \\
=1.940 \\
=4.260\end{array}$ \\
\hline
\end{tabular}

inlet temperature of $315 \mathrm{~K}$, mass flow rate of $1 \times 10^{-4}$ $\mathrm{kg} / \mathrm{s}$ and heat flux of $0.7 \mathrm{MW} / \mathrm{m}^{2}$.Addition of PCM particles reduces the mean flow temperature and increases the viscosity which leads to increase volumetric entropy generation rate due to fluid friction [4]. It is found that the volumetric entropy generation rate due to fluid friction is increased by $12 \%, 34 \%, 63 \%, 104 \%$ and $143 \%$ for $5 \%, 10 \%$, $15 \%, 20 \%$ and $25 \%$ PCM slurry respectively, as compared to water ( $0 \%$ PCM slurry).

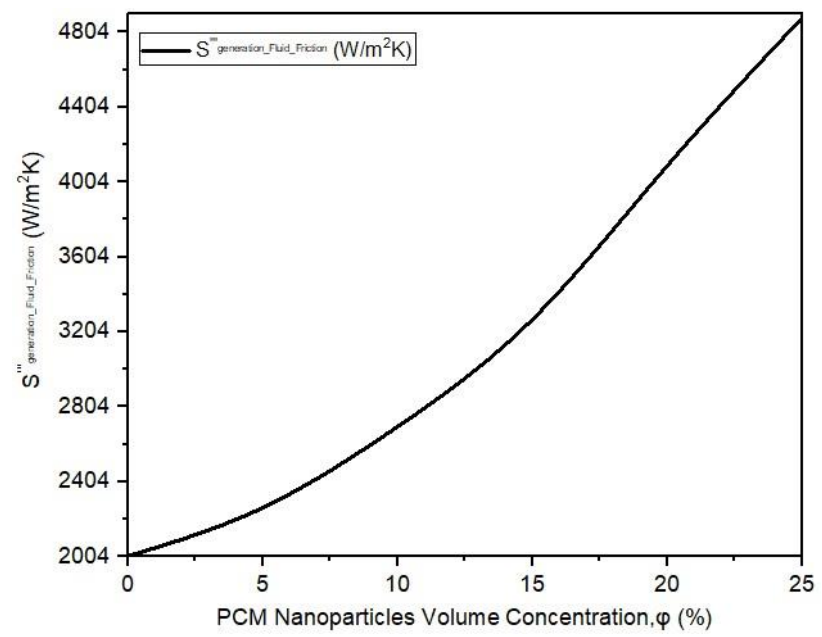

Figure 8 - shows the volumetric entropy generation rate due to fluid friction as a function of particle volume concentration $(0-25 \%)$

\section{Effectiveness Index}

Effectiveness index is ratio of enhancement in heat transfer to increase in pumping power due to the addition of PCM particles in carrier fluid, defined as Effectiveness index $=$

$$
\frac{E f f_{\text {pcms }}-E f f_{\text {water }}}{E f f_{\text {water }}} / \frac{P P_{p c m s}-P P_{\text {water }}}{P P_{\text {water }}}
$$

Fig. 9 shows effectiveness index as a function of particle volume concentration $(0-25 \%)$ in microchannel at inlet temperature of $315 \mathrm{~K}$, mass flow rate of $1 \times 10^{-4} \mathrm{~kg} / \mathrm{s}$ and heat flux of $0.7 \mathrm{MW} / \mathrm{m}^{2}$.
The result shows that effectiveness index increases by increasing PCM particle volume concentration below $11 \%$ after $11 \%$ the effectiveness index decreases. This is because with the addition of PCM particles the viscosity of the PCM slurry increases which in turn increase the pumping power requirement and gain in effectiveness is compensated by demands of pumping power. The highest effectiveness index of 0.36 is recorded for Particle volume concentration of $11 \%$.

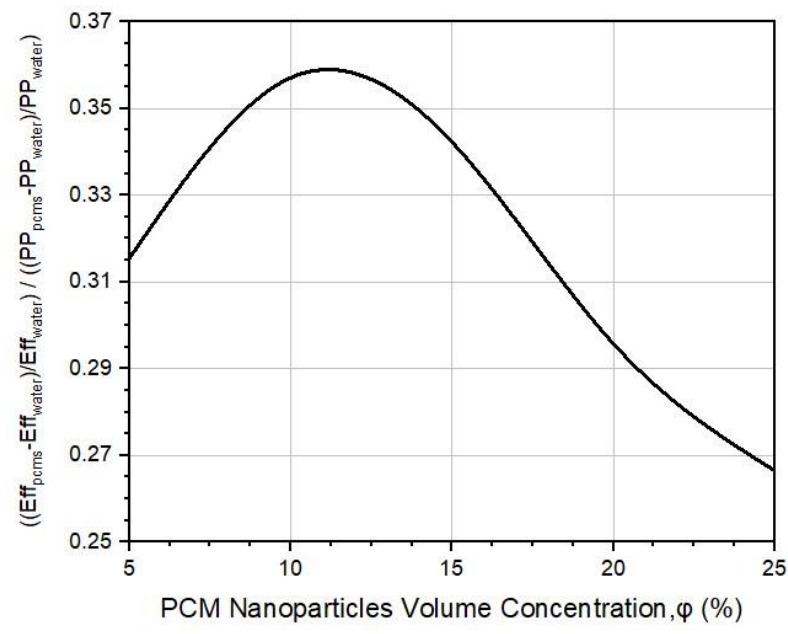

Figure 9 - Effectiveness index as a function of particle volume concentration (0-25\%) 


\begin{tabular}{|c|c|c|c|c|c|c|}
\hline Impact Factor: & $\begin{array}{l}\text { ISRA (India) } \\
\text { ISI (Dubai, UAE } \\
\text { GIF (Australia) } \\
\text { JIF }\end{array}$ & $\begin{array}{l}=1.344 \\
=0.829 \\
=0.564 \\
=1.500\end{array}$ & $\begin{array}{l}\text { SIS (USA) } \\
\text { PИНЦ (Russia) } \\
\text { ESJI (KZ) } \\
\text { SJIF (Morocco) }\end{array}$ & $\begin{array}{l}=0.912 \\
=0.207 \\
=4.102 \\
=\mathbf{2 . 0 3 1}\end{array}$ & $\begin{array}{l}\text { ICV (Poland) } \\
\text { PIF (India) } \\
\text { IBI (India) }\end{array}$ & $\begin{array}{l}=6.630 \\
=1.940 \\
=4.260\end{array}$ \\
\hline
\end{tabular}

\section{Conclusion}

Numerical model investigated the effect of using phase change material slurries (PCMs) on the hydraulic performance of microchannel used for cooling of high heat generating small scale devices. Under specific conditions including mass flow rate $1 \times 10^{-4} \mathrm{~kg} / \mathrm{s}$, heat flux $0.7 \mathrm{MW} / \mathrm{m}^{2}$, inlet temperature of $315 \mathrm{~K}$ and PCM nano-particles volume concentration $(0-25 \%)$.It is found that for the same temperature rise, $25 \%$ PCM slurry can store up to $52 \%$ more heat as compared to 0\% PCM slurry (water). The maximum relative increase of $197 \%$, $21 \%$ and $143 \%$ in pumping power, volumetric entropy generation rate due to heat transfer and volumetric entropy generation rate due to fluid friction respectively is recorded for 25\% PCM slurry, as compared to water ( $0 \%$ PCM slurry). The maximum effectiveness index of 0.36 is recorded for $11 \%$ PCM slurry. This means that 11\% PCM slurry stores more heat with less pressure drop along the microchannel as compared to other slurries.

\section{Acknowledgment}

Thankful to National University of Sciences \& Technology-Pakistan and Arizona State UniversityUSA for providing the incredible opportunities to develop academic, social, and intellectual repertoire. And deeply grateful to USAID Pakistan for sponsorship and support.

\section{References:}

1. Awad B.S. Alquaity, Salem A. Al-Dini, Evelyn N. Wang, Bekir S. Yilbas (2012) "Numerical investigation of liquid flow with phase change nanoparticles in microchannels" International Journal of Heat and Fluid Flow 38, pp. 159167, Nov. 2012.

2. Lalit Roy, M. A. R. Sharif (2017) "Numerical analysis of electronic substrate cooling by pumping nanoencapsulated phase change material slurry through micro-channels etched on the substrate" AIP Conference Proceedings 1851, 020028, 2017.

3. Rami Sabbah, Mohammad M. Farid, Said AlHallaj (2008) "Micro-channel heat sink with slurry of water with micro-encapsulated phase change material: 3D-numerical study" Applied Thermal Engineering, pp. 445-454, Mar. 2008.

4. Awad B.S. Alquaity, Salem A. Al-Dini, B. S. Yilbas (2012) "Entropy generation rate in microchannel flow with phase change particles" Journal of Thermophysics and Heat Transfer, Vol. 26, pp. 134-140, 2012.

5. Kuravi, S., Kota, K.M., Du, J., Chow, L.C. (2009) "Numerical Investigation of Flow and Heat Transfer Performance of NanoEncapsulated Phase Change Material Slurry in Microchannels" Journal of Heat Transfer, pp. 62901-62907, Mar. 2009.

6. Manish Goel, S. K Roy, S. Sengupta (1994) "Laminar forced convection heat transfer in microencapsulated Phase Change Material suspension” Int. J. Heat Mass Trasfer, vol. 37,pp.1593-604, 1994.
7. Binjiao Chen, Xin Wang, Ruolang Zeng, Yinping Zhang, Xichun Wang, Jianlei Niu, Yi Li, Hongfa Di (2008) "An experimental study of convective heat transfer with microencapsulated phase change material suspension: Laminar flow in a circular tube under constant heat flux " Experimental Thermal and Fluid Science 32, pp. 1638-1646, May 2008.

8. Roy, S.K., Avanic, B.L. (1997) "Laminar forced convection heat transfer with phase change material emulsions" Int. Commun. Heat Mass Transfer 24, pp. 653-662, 1997.

9. Xing, K.Q., Tao, Y.X., Hao, Y.L. (2005) "Performance evaluation of liquid flow with PCM particles in microchannels" J. Heat Transfer 127,pp. 931-940, 2005.

10. Yutang Fang, Shengyan Kuang, Xuenong Gao and Zhengguo Zhang (2009) "Preparation of nanoencapsulated phase change material as latent functionally thermal fluid" J. Phys. D: Appl. Phys. 42, pp. 035407 (8pp), 2009.

11. Satyanarayana Kondle, Jorge L. Alvarado, Charles Marsh (2013) "Laminar Flow Forced Convection Heat Transfer Behavior of a Phase Change Material Fluid in Microchannels" Journal of Heat Transfer, pp. 052801,1052801,11, 2013.

12. Vand, V. (1945) Theory of viscosity of concentrated suspensions. Nature (London) 155, pp. 364-365, 1945.

13. Maxwell, J.C. (1954) A Treatise on Electricity and Magnetism, third ed. Dover, New York, vol. 1, pp. 440-441, 1954. 